ISSN 0258-7122

Bangladesh J. Agril. Res. 37(1): 129-136, March 2012

\title{
GENETIC DIVERGENCE IN CHICKPEA (Cicer arietinum L.)
}

\author{
M. A. SYED ${ }^{1}$, M. R. ISLAM², M. S. HOSSAIN ${ }^{2}$ \\ M. M. ALAM ${ }^{3}$ AND M. N. AMIN ${ }^{4}$
}

\begin{abstract}
Genetic diversity of 27 chickpea genotypes was studied through Mahalanobis $\mathrm{D}^{2}$ and Principal Component analysis. The genotypes under study fall into five clusters. The cluster II contained the highest number of genotypes (11) and Cluster I contained the lowest. Cluster I produced the highest mean value for number of pods per plant. The inter cluster distances were much higher than the intra cluster distances. Cluster V exhibited the highest intra cluster distance while the lowest distance was observed in cluster I. The highest inter cluster distance was observed between cluster I and II while the lowest was between cluster III and V. Considering all the characters, it was suggested that the genotypes BD6549, BD6603, and BD6548 could used as parents for future breeding programs to develop high yielding varieties of chickpea.
\end{abstract}

Keywords: Chickpea, genetic diversity, multivariate, $\mathrm{D}^{2}$ statistics, inter cluster distance and intra cluster distance.

\section{Introduction}

Chickpea (Cicer arietinum L.) belongs to the family Fabaceae. On the basis of cultivated area, chickpea ranks $19^{\text {th }}$ among the crops, and is grown in 34 countries of the world. Area under pulses in India, Pakistan, Nepal, and Bangladesh covers about $90 \%$ of the world acreage (Saxena, 2001). In Bangladesh, chickpea is the third major pulse crop after grass pea (Khesari) and lentil (Islam et al., 1981 and Anon, 1998). Pulses covered about 225711.74 ha of cultivated area of Bangladesh of which chickpea covered 9352.63 ha in 2008 and produced 7168 metric tons with an average yield of $0.76 \mathrm{mt} / \mathrm{ha}$ (BBS, 2008).

Chickpea is the second most important pulse crop in the world after dry bean. It is an important source of human and animal food. It also helps to improve soil fertility particularly in dry lands. Introduction of chickpea in a cereal based rotation which is used particularly in developing countries can break the disease and pest cycle, and increase the productivity of the entire rotation (Jodha and Subba Rao, 1987).

\footnotetext{
${ }^{1}$ Plant Breeding Division, Bangladesh Rice Research Institute (BRRI), Gazipur, ${ }^{2}$ Department of Genetics and Plant Breeding, Sher-e-Bangla Agricultural University (SAU), Dhaka, ${ }^{3}$ Department of Agronomy, SAU, Dhaka, ${ }^{4}$ Plant Breeding Division, Bangladesh Agricultural Research Institute (BARI), Gazipur, Bangladesh.
} 
Chickpea is the cheapest and readily available source of protein (17\%), fats (23\%), carbohydrates (61.2\%), and 9.8\% moisture (Smartt, 1976). Chickpea seeds contain essential amino acids like isoleucine, leucine, lysine, phenylalanine, and valine (Karim and Fattah, 2006). The total protein supply in our expanding population is decreasing day by day. A part of this problem can be solved by increasing the per hectare production and utilization of chickpea. The soil and climatic conditions of Bangladesh are suitable for growing chickpea in winter (robi) season. Limited work is being done for the improvement of the crop in our country. Recently different lines of this crop have been introduced and evaluated for selection of desirable types of varieties for Bangladesh.

\section{Materials and Method}

The experiment was conducted at the experimental field of Sher-e-Bangla Agricultural University (SAU), Dhaka-1207, Bangladesh during the period from October 2008 to March 2009. The experimental area was situated at $23^{\circ} 77^{\prime} \mathrm{N}$ latitude and 99 $93^{\prime} \mathrm{E}$ longitude at an altitude of 8.6 meter above the sea level (Anon., 2004). The experimental field belongs to the agro-ecological zone of The Modhupur Tract AEZ-28 (Anon, 1988a). Soil pH ranged from 6.1 to 6.3 and organic matter was $0.84 \%$. Twenty elite genotypes and seven varieties were used for the research work. The genetically pure and physically healthy seeds of these genotypes were collected from Plant Genetic Resource Centre (PGRC) and Pulses Research Centre of Bangladesh Agricultural Research Institute (BARI). The experiment was laid out in Randomized Complete Block Design (RCBD) with three replications. Before sowing, 10 tons cowdung, $14 \mathrm{~kg}$ nitrogen, $33 \mathrm{~kg}$ $\mathrm{P}_{2} \mathrm{O}_{5}$ and $15 \mathrm{~kg} \mathrm{~K}_{2} 0$ were applied per hectare. The seeds were sown in row on 12 November 2008 maintaining row distance of $40 \mathrm{~cm}$. Seeds were placed at 2-3 cm depth in each row keeping $15 \mathrm{~cm}$ distance between two hills. Two seeds were sown in each hill. The excess plants were thinned out keeping one plant in each hill at 15 days after sowing (DAS). The young plants were irrigated by watercan to maintain soil moisture at field capacity. The recommended agronomic practices were followed to get a good crop.

Number of days to flowering was recorded at the time when at least $50 \%$ plants showed the appearance of first flower. Days taken to maturity were calculated from the date of planting to the date when $90 \%$ plants turned brown and ready for harvest. At maturity, ten plants were selected per plot at random to record data on plant height, primary branches per plant, secondary branches per plant, pods per plant, 100-seed weight, and seed yield per plant.

Genetic diversity was estimated by $\mathrm{D}^{2}$ analysis originally proposed and outlined by Mahalanobis (1928 and 1936) and extended by Rao (1952). Mean

data of the characters were subjected to Multivariate analysis using GENSTAT 5.13 and Microsoft Excel 2000 software through four techniques viz. Principal 
Component Analysis (PCA), Principal Coordinate Analysis (PCO), Cluster Analysis (CA) and Canonical Vector Analysis (CVA). Mean, range and coefficient of variance (CV) were also estimated using Mstat C.

\section{Results and Discussion}

Before diversity analysis, range, mean, standard deviation and co-efficient of variation of the different characters of the studied germplasm were measured (Table 1). Maximum variation was found in number of pods/plant followed by number of primary branches/plant and seed yield/plant. Other characters also showed considerable variability.

Table 1. Range, mean, standard deviation and co-efficient of variation among different characters of cheakpea genotypes.

\begin{tabular}{lcc|c|c}
\hline Character & Range & Mean & SD & CV(\%) \\
\hline Plant height (cm) & $31-47$ & 37.19 & 4.62 & 12.43 \\
No. of primary branches/plant & $2-5.5$ & 3.28 & 0.96 & 29.24 \\
No. of secondary branches/plant & $15.33-43$ & 32.90 & 7.09 & 21.54 \\
Days to 50\% flowering & $38.33-48.33$ & 43.21 & 2.85 & 6.60 \\
Days to 100\% flowering & $45.33-55.33$ & 50.21 & 2.72 & 5.42 \\
No. of pods / plant & $17.33-87$ & 37.74 & 13.11 & 34.74 \\
100 seed weight (g) & $9.25-21.73$ & 14.83 & 3.40 & 22.94 \\
Seed yield/ plant (g) & $3.12-12.39$ & 7.72 & 2.20 & 28.52 \\
\hline
\end{tabular}

Based on the cluster analysis, 27 genotypes of chickpea were grouped into five clusters (Table 2). Cluster II was the largest and consisted of 11 genotypes followed by cluster III which had 7 genotypes. The cluster V had 5 and cluster IV had 3 genotypes. Cluster I was unique in having only one genotype. It was observed from the distribution pattern that the geographic divergence did not follow the same trend as the varieties/genotypes within the same cluster originated from different countries. The clustering pattern of the genotypes under study did not necessarily follow their geographical distribution. However, those were distributed at random. The geographical distribution was in agreement with Devi et al. ( 2004) who reported that the pattern of clustering had no general association between ecological distribution of genotypes and genetic divergence. This might be due to differential adoption, selection criteria, selection pressure, and environment. Murty and Arunanchalam (1996) reported that genetic drift and selection in different environments could cause greater diversity than the geographic distance. 
Table 2. Distribution of $\mathbf{2 7}$ genotypes of chick pea in five clusters.

\begin{tabular}{|c|c|c|c|}
\hline Cluster & $\begin{array}{l}\text { No. of } \\
\text { genotypes }\end{array}$ & Genotype number & Name of the genotype \\
\hline I & 1 & 21 & BD 6603 \\
\hline II & 11 & $\begin{array}{l}1,6,7,8,11,12 \\
20,22,23,24,25\end{array}$ & $\begin{array}{l}\text { BARI Chola 1, BARI Chola 6, } \\
\text { BARI Chola 7, BD 6497,BD 6548, } \\
\text { BD 6549, BD 6602, BD 6618, BD } \\
\text { 6621, BD 6635, BD } 6637\end{array}$ \\
\hline III & 7 & $\begin{array}{l}5,9,10,14,15 \\
16,27\end{array}$ & $\begin{array}{l}\text { BARI Chola 5, BD 6534, BD } \\
\text { 6536, BD } 6584, \text { BD 6587, BD } \\
\text { 6588, BD } 6760\end{array}$ \\
\hline IV & 3 & $3,17,19$ & $\begin{array}{l}\text { BARI Chola 3, BD 6589, BD } \\
6599\end{array}$ \\
\hline $\mathrm{V}$ & 5 & $2,4,13,18,26$ & $\begin{array}{l}\text { BARI Chola 2, BARI Chola 4, BD } \\
\text { 6552, BD 6597, BD } 6638\end{array}$ \\
\hline
\end{tabular}

Inter and Intra cluster distances are presented in the Table 3 and Fig.1, which revealed that the inter cluster distances in all cases were larger than intra cluster distances suggesting wider genetic diversity among the genotypes of different groups.

Table 3. Average intra (Bold) and inter cluster distances $\left(D^{2}\right)$ for 27 genotypes of chickpea.

\begin{tabular}{c|c|c|c|c|c}
\hline \multirow{2}{*}{ Cluster } & \multicolumn{5}{|c}{ Cluster distance } \\
\cline { 2 - 6 } & I & II & III & IV & V \\
\hline I & $\mathbf{0 . 0 0}$ & & & & \\
II & 16.35 & $\mathbf{0 . 3 1}$ & & & \\
III & 13.05 & 4.00 & $\mathbf{0 . 4 4}$ & & \\
IV & 12.70 & 4.00 & 3.45 & $\mathbf{0 . 5 3}$ & \\
V & 11.64 & 6.56 & 2.61 & 5.47 & $\mathbf{0 . 5 4}$ \\
\hline
\end{tabular}

The highest inter cluster distance was observed between clusters I and II (16.35), followed by I and III (13.05), I and IV (12.70) and I and V (11.64) which indicated that the genotypes grouped in these clusters were highly divergent from each other. Similar findings were reported by Lal et al. (2001). 


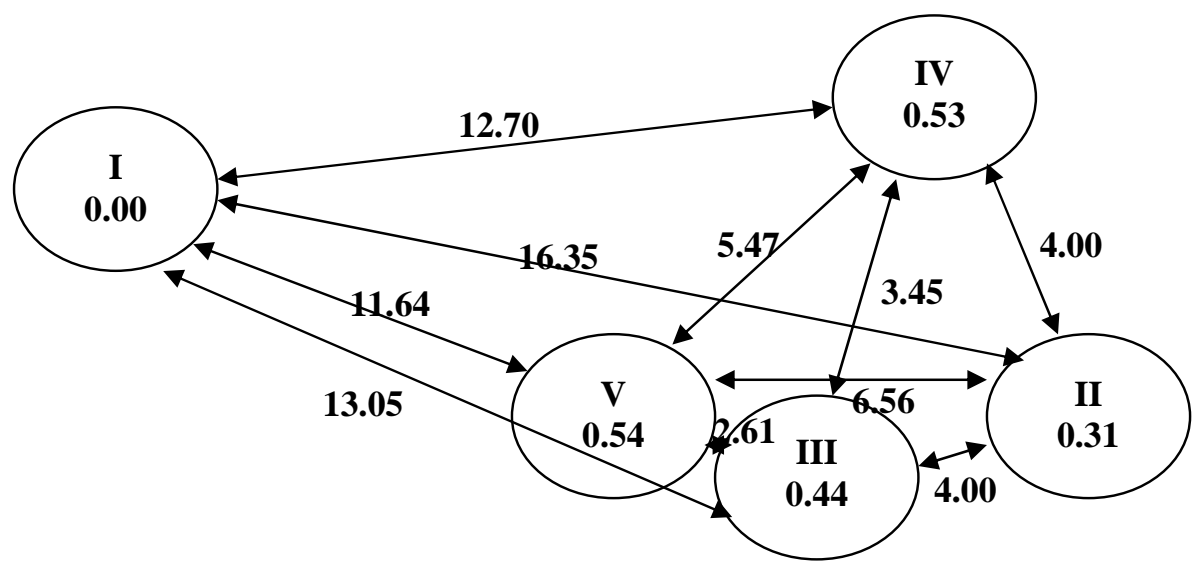

Fig. 1. Diagram showing intra and inter-cluster distances of 27 genotypes of chickpea.

Choosing parents belonging to the maximum divergent clusters are expected to manifest maximum heterosis in crossing and wide variability in genetic architecture (Chowdhury et. al., 2002). The least genetic distance at inter cluster level was observed between clusters III and V (2.61) followed by III and IV (3.45), II and IV (4.00) and IV and V (5.47) which indicated that the genotypes of these clusters were genetically close. Intra cluster distances were estimated using inter genotypic distance, as quoted of Singh and Choudhary (1985).

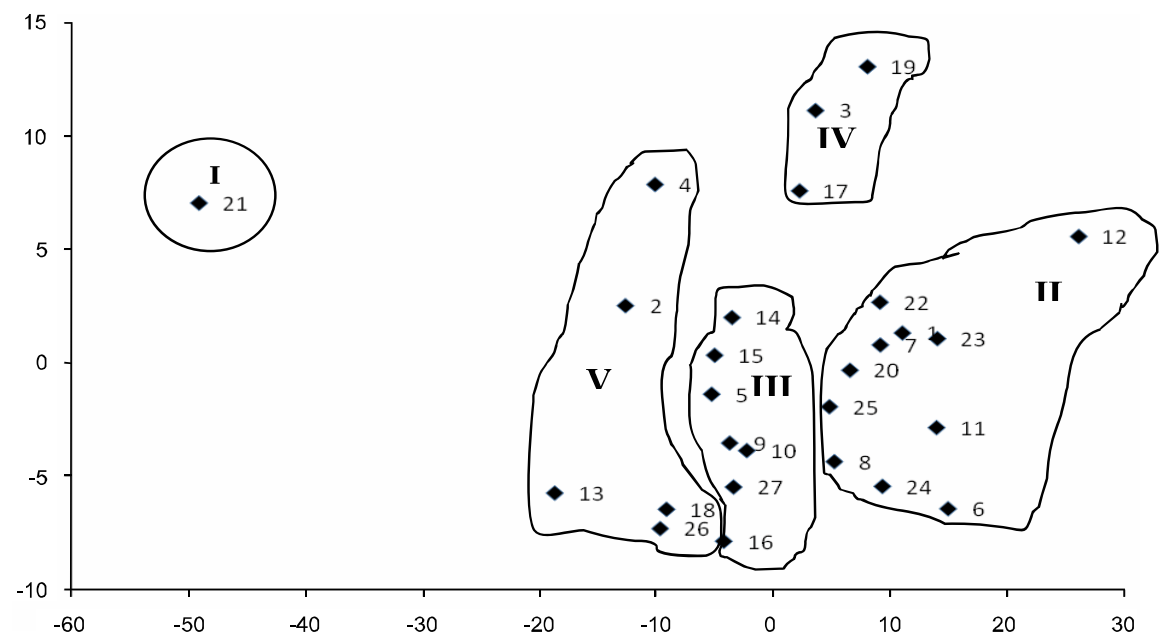

Fig. 2. Scatter distribution of 27 genotypes of chickpea based on their principal component scores superimposed with clusters. 
The clustering pattern of $\mathrm{D}^{2}$ analysis followed the similar trend of distribution of genotypes in PCA (Fig.2). The $\mathrm{D}^{2}$ and PCA were found to be alternative methods in yielding information regarding the clustering pattern. Moreover, the PCA provided information on contribution of the characters towards divergence (Table 3).

The cluster mean values of 27 chickpea genotypes are presented in Table 3 while comparing of cluster means for different characters. Cluster I had the highest mean values for primary branches per plant, secondary branches per plant, number of pods per plant and seed yield per plant. None of 8 characters had high mean values under cluster II and V. Cluster III had the highest means for $50 \%$ flowering and $100 \%$ flowering. Cluster IV comprising of three genotypes, showed the highest mean values for plant height and 100 seed weight (g). Concomitant result has been reported by Kumar et al., 1998.

Table 4. Cluster mean for $\mathbf{8}$ characters of 27 genotypes of chickpea.

\begin{tabular}{l|c|c|c|c|c}
\hline \multirow{2}{*}{ Character } & \multicolumn{5}{c}{ Cluster } \\
\cline { 2 - 6 } & I & II & III & IV & V \\
\hline Plant height (cm) & 41.67 & 34.73 & 37.21 & 44.11 & 37.00 \\
$\begin{array}{l}\text { No. of primary } \\
\text { branches/plant }\end{array}$ & 5.28 & 2.98 & 2.98 & 3.75 & 3.12 \\
$\begin{array}{l}\text { No. of secondary } \\
\text { branches/plant }\end{array}$ & 42.00 & 26.73 & 36.54 & 27.22 & 41.00 \\
$\begin{array}{l}\text { Days to 50\% flowering } \\
\text { Days to 100\% }\end{array}$ & 43.00 & 43.83 & 44.46 & 42.11 & 40.67 \\
flowering & 50.00 & 50.83 & 51.46 & 49.11 & 47.67 \\
No. of pods / plant & 87.00 & 27.67 & 39.42 & 34.67 & 47.20 \\
100-seed weight (g) & 15.94 & 14.40 & 13.39 & 21.26 & 13.91 \\
Seed yield/ plant (g) & 12.39 & 6.70 & 7.29 & 9.59 & 8.41 \\
\hline
\end{tabular}

Contribution of the characters towards divergence is presented in Table 4. The Canonical variate analysis revealed that in the both vectors (Vector I and Vector II) number of secondary branches per plant (0.11 and 0.29) and seed yield per plant (0.01 and 0.02) were positive. Such results indicated that these characters contributed maximum towards divergence of the genotypes. In vector I plant height, days to $50 \%$ flowering, days to $100 \%$ flowering, number of pods per plant and 100 seed weight played significant role. The greater divergence in the present material due to those characters will offer a good scope for improvement of yield through rational selection of parents for producing heterotic genotypes. 
Table 5. Latent vectors for 8 principal component characters of 27 genotypes of chickpea.

\begin{tabular}{lcc}
\hline \multicolumn{1}{c}{ Character } & Vector I & Vector II \\
\hline Plant height (cm) & 0.05 & -0.09 \\
No. of primary branches/ plant & -0.25 & -0.66 \\
No. of secondary branches/ plant & 0.11 & 0.29 \\
Days to 50\% flowering & 0.04 & -0.09 \\
Days to 100\% flowering & 0.04 & -0.09 \\
No. of pods/plant & 0.24 & -0.10 \\
100 seed weight(g) & 0.22 & -0.10 \\
Seed yield/ plant(g) & 0.01 & 0.02 \\
\hline
\end{tabular}

\section{References}

Anonymous. 2004. FAO Irrigation and Drainage Paper. Food and Agriculture Organization of the United Nations, Rome, Italy. 3: 80-82.

Anonymous. 1998. Statistical Yearbook of Bangladesh. Bangladesh Bureau of Statistics, Ministry of Planning, Govt. People’s Republic of Bangladesh. 61-64 pp.

Anonymous. 1988a. Review of Vegetable Crop Programme Mennonite Central Committee (MCC), Bangladesh. 26-35 pp.

BBS. 2008. Bangladesh Bureau of Statistics. Yearbook of Agriculture Statistics of Bangladesh. Ministry of Planning, Government of the People's Republic of Bangladesh. $126 \mathrm{p}$.

Chowdhary, M. A., V. Vanderberg and T. Warkentin. 2002. Cultivar identification and genetic relationship among selected breeding lines and cultivars in chickpea (Cicer arietinum L.). Euphytica 172: 317-325.

Devi, L. S., A. Das, M. K. Pandey and C. R. Kole. 2004. Studies on genetic variability and divergence in rice: Extended Summery, Int. Symp. on rice: From Green Revolution to Gene Revolution. Oct. 04-06, DRR, Hyderabad, India. 94 p.

Islam, M. Q., A. T. Sarker, M. Quader and L. Begum. 1981. Status of Chickpea Improvement at BARI. In Proc. National Workshop on Pluses at Joydebpur. A. K. Kaul (Ed.)1982. 56-64 pp.

Jodha, N. S. and K. V. Subba Rao. 1987. The Chickpea. In: Chickpea: World Importance and Distribution (Eds: M. C. Saxena and K. B. Singh), CAB International, Wallingford, Oxon, UK. 1-10 pp.

Karim, M. F. and Q. A. Fattah. 2006. Changes in biocomponents of chickpea (Cicer arietinum L.) sprayed with potassium napthenate and napthenic acetic acid. Bangladesh J. Bot. 35 (1): 39-43.

Kumar, A., R. Krishna and S. K. Chaturvedi. 1998. Genetic divergence in chickpea (Cicer arietinum L.). Ind. J. Genet. Plant Breed. 58(3): 337-342. 
Lal, D., Ram Krishna and S. Gurpreet. 2001. Genetic divergence in chickpea. Ind. J. Pulses Res. 14(1): 63-64.

Mahalanobis, P. C. 1928. A statistical study at Chinese head moaurement. Man in India 8: 32-64.

Mahalanobis, P. C. 1936. On the generalized distance in statistics. Proc. Nat. Inst. Sci. India. 2: 49-55.

Murty, B. R. and V. Arunachalam. 1996. The nature of divergence in relation to breeding system in some crop plants. Ind. J. Genet. Plant Breed. 26(4): 188-198.

Rao, C. R. 1952. Advanced Statistical Methods in Biometrical Research. John Wiley and Sons, New York. 45-110 pp.

Saxena, M. P., R. Goldworthy and N. M. Righer. 2001. Chickpea. The Physiology of Tropical Field Crops. John Willey and Sons. 419-452 pp.

Singh, R. K. and B. P. Chaudhary. 1985. Biometrical methods of quantitative genetic analysis. Haryana J. Hort. Sci. 12 (2): 151-156.

Smartt, J. 1976. Tropical Pulses. Tropical Agriculture Series: Southampto Univ. Longman Group Ltd., London. 96 p. 